\title{
FEEDING EFFECT OF INULIN DERIVED FROM DAHLIA TUBER COMBINED WITH Lactobacillus sp. ON MEAT PROTEIN MASS OF CROSSBRED KAMPONG CHICKEN
}

\author{
Z. H. Abdurrahman, Y. B. Pramono and N. Suthama \\ Faculty of Animal and Agricultural Sciences, Diponegoro University, \\ Tembalang Campus, Semarang 50275 - Indonesia \\ CorrespondingE-mail:nsuthama@gmail.com
}

Received November 30, 2015; Accepted Febraury 28, 2016

\begin{abstract}
ABSTRAK
Penelitian bertujuan untuk mengevaluasi pengaruh pemberian tepung umbi dahlia yang dikombinasikan dengan Lactobacillus species (Lactobacillus sp.) terhadap aktifitas antioksidan, massa kalsium, dan massa protein pada daging ayam kampung persilangan. Ternak penelitian adalah ayam kampung persilangan umur satu hari unsex sebanyak 168 ekor diberi perlakuan mulai umur 3 minggu. Penelitian menggunakan rancangan acak lengkap pola faktorial $2 \times 3$ dengan 4 ulangan. Faktor pertama adalah pemberian dua level tepung umbi dahlia yaitu $0,8 \%$ (A1) dan $1,2 \%$ (A2), dan faktor kedua adalah pemberian tiga level Lactobacillus sp. yaitu tanpa penambahan (B0), 1,2 $\mathrm{mL}\left(10^{8} \mathrm{cfu} / \mathrm{mL}\right)(\mathrm{B} 1)$ dan 2,4 $\mathrm{mL}\left(10^{8} \mathrm{cfu} / \mathrm{mL}\right)(\mathrm{B} 2)$. Parameter yang diamati adalah aktifitas antioksidan, massa kalsium, dan massa protein daging. Data dianalisis ragam dan jika terdapat pengaruh nyata $(\mathrm{P}<0,05)$ dilanjutkan dengan $\mathrm{Uji}$ wilayah ganda Duncan. Hasil penelitian menunjukkan bahwa pemberian tepung umbi dahlia sebagai sumber inulin dikombinasikan dengan Lactobacillus sp. nyata $(\mathrm{P}<0,05)$ meningkatkan nilai aktifitas antioksidan dan massa protein daging, tetapi tidak terhadap massa kalsium daging. Pemberian tepung umbi dahlia 1,2\% dan Lactobacillus sp. 1,2 $\mathrm{mL}\left(10^{8} \mathrm{cfu} / \mathrm{mL}\right)$ merupakan kombinasi terbaik dilihat dari peningkatan aktifitas antioksidan dan massa protein daging.
\end{abstract}

Kata Kunci: inulin umbi dahlia, Lactobacillus sp., daging ayam kampung persilangan

\begin{abstract}
The objective of the study was to determine the effects of feeding Lactobacillus species (Lactobacillus sp.) and inulin derived from dahlia tuber powder on antioxidant activity, calcium mass, and protein mass of crossbred kampong chicken meat. A total of 168 birds of 21 days old crossbred kampong chickens were randomly allocated into 6 treatments with four replications per treatment. The present experiment was assigned in a completely randomized design with $2 \times 3$ factorial scheme. The first factor was levels of dahlia tuber powder, namely $0.8 \%$ (A1) and $1.2 \%$ (A2), and the second factor was levels of Lactobacillus sp., namely none (B0), $1.2 \mathrm{~mL}\left(10^{8} \mathrm{cfu} / \mathrm{mL} / \mathrm{B} 1\right)$ and $2.4 \mathrm{~mL}\left(10^{8}\right.$ $\mathrm{cfu} / \mathrm{mL} / \mathrm{B} 2)$. The parameters measured were antioxidant activity, meat calcium and protein mass. Data were subjected to analysis of variance and followed by Duncan multiple range test $(\mathrm{P}<0.05)$ when the treatment indicated significant effect. The supplementation of dahlia tuber powder and Lactobacillus sp. significantly $(\mathrm{P}<0.05)$ increased antioxidant activity and protein mass of meat. However, calcium mass of meat was not significantly affected by treatments. In conclusion, feeding dahlia tuber powder at the level of $1.2 \%$ combined with Lactobacillus sp. at $1.2 \mathrm{~mL}\left(10^{8} \mathrm{cfu} / \mathrm{mL}\right)$, can be categorized as the best combination based on the increase in antioxidant activity and meat protein mass.
\end{abstract}

Keywords: inulin of dahlia tuber, Lactobacillus sp., crossbred kampong chicken meat 


\section{INTRODUCTION}

Poultry farming plays a major role in the fulfillment of food demand derived from animal product, especially poultry meat. Kampong chicken (Gallus gallus) is one poultry breed that can be a potential source of meat producer. This local chicken has been known since ancient times and has an important role same as other poultry. Kampong chicken is still being the interesting preference of poultry commodity for the Indonesian community (Pramono, 2006). Considering the low productivity and slow growth, it is important to find the way to improve the productivity of kampong chicken by crossbreeding system (Rahayu et al., 2010). The fillial produced through cross-mating model is known as crossbred kampong chicken. Although the productivity of crossbred kampung chicken is claimed to be slightly better than their uncester, the gaining is still lower than that of modern poultry. Therefore, the effort to improve the productivity of crossbred kampong chicken is still required. In the previous decade antibiotic in poultry production system was very common substance to be used as growth promoter. However, nowadays, antibiotic is no longer recommended as the growth promoter and it has been baned in the world-wide, because it might cause residue in poultry product and bacterial resistance which harmful for the consumer. Natural substance as an alternative for antibiotic has been the popular compound that can be able to improve productivity of poultry and also consumer health friendly. As it has been reported previously by Verdonk et al. (2005) that the natural substance of feed supplement can ensure to be beneficial for the host animals. Feeding the promising substance of natural compound, probiotic combined with prebiotic, was evaluated for crossbred kampong chicken in the present study.

Probiotic is a live microbial feed supplement in adequate quantities that beneficially influences the host animal by improving the intestinal microflora ecosystem. Source of probiotic both Lactobacili and Bifidobacteria can easily and quickly use prebiotic, such as inulin, as a source of "feed ingredient" for fermentation to produce lactate, and short chain fatty acids (SCFAs), including acetate, propionate, and butyrate (Kelly, 2008). The products of fermentation process as described above bring about the change of the intestinal $\mathrm{pH}$ to be acidic condition which in turn favorable for the growth of the beneficial bacteria and lead to the improvement of gut health.

One compound can functions as a "partner" of probiotic is known as prebiotic. Prebiotic is food ingredient that can't be digested by the enzymes and providing a beneficial effect to the host by stimulating the growth or the activity of selective microbes in the intestine (Fuller, 1989, and Choudhari et al., 2008). Prebiotic is also a residual-free natural compound and no harmful for consumer's health. The increase in the number and activity of Bifidobacteria and lactic acid bacteria (Lactobacillus) which provided the impact on nutrients utilization and lead to the improved productivity is the beneficial effect of prebiotic for the host. A source of natural prebiotic, known as inulin, derived from the tuber of Indonesian local plant, called dahlia (Dahlia variabilis), was evaluated in the present study. The total inulin content of dahlia tuber was about $65-75 \%$ from the total carbohydrate (Haryani et al., 2013). Dahlia is also specified as the highest inulin-producing plant containing fructose and active compounds such as phytic and benzoic acids (Shivayogeppa et al., 2009). Among other sources, inulin was the best prebiotic (Azhar, 2009) and water soluble which can't be digested by host digestive enzymes, but can be selectively fermented by intestinal microbes. Roberfroid (2007) reported that inulin function as "feed ingredient" can be almost completely fermented by Bifidobacteria and Lactobacilli.

The utilization of local resources such as dahlia tuber as a source of prebiotic inulin combined with Lactobacillus sp. is expected to be a synbiotic and have an impact on the increase in nutrients utilization and productivity of crossbred kampong chicken. As a comparisson, feeding phytobiotic contained a combination of probiotic and prebiotic substances has been reported to function as natural growth promoter (NGPs) (Panda et al., 2009). Therefore, the present study was conducted to evaluate the effect of inulin derived from dahlia tuber combined with Lactobacillus sp. on antioxidant activity and meat production quality based on calcium and meat protein mass, and to determine the beneficially appropriate combining levels of both substances in crossbred kampong chicken.

\section{MATERIALS AND METHODS}

The experimental animals used in the present study were 168 birds of day old unsex crossbred 
kampong chicken. The basal diet was composed with protein and energy contents of $19 \%$ and $2,800 \mathrm{kcal} / \mathrm{kg}$, rescpectively, for starter period, and $18 \%$ and $2,800 \mathrm{kcal} / \mathrm{kg}$, recpectively, for finisher period (Table 1).

Day old chicks were kept until 15 days in the brooder cage and fed a standard commercial poultry feed (AD11). The birds were adapted to experimental diet during the period of 15 to 20 days, before starting the main experiment. The test diets were provided on day 21 until 2.5 months of age. Twenty one day old chickens were then randomly allocated into 168 units of battery cage of $25 \times 35 \times 30 \mathrm{~cm}$ in size each. Seven birds were housed in each unit of battery. The experimental chickens were given ad libitum to diet and drinking water. Chicken were fed twice a day at $06.00 \mathrm{am}$ and $16.00 \mathrm{pm}$. A small portion of diets (about $20 \mathrm{~g}$ ) were mixed with dahlia tuber powder and Lactobacillus sp., according to the level of respective treatment, and were given at $16.00 \mathrm{pm}$ every afternoon to ensure both substances can be completely consumed before feeding other portion of diet.

Experimental design of a $2 \times 3$ factorial scheme in a completely randomized design with 4 replications was assigned in the present study. The first factor was 2 levels of dahlia tuber powder, namely $0.8 \%$ (A1) and $1.2 \%$ (A2), and the second factor was 3 additional levels of Lactobacillus sp., namely none (B0), $1.2 \mathrm{~mL}\left(10^{8} \mathrm{cfu} / \mathrm{mL} / \mathrm{B} 1\right)$, and $2.4 \mathrm{~mL}\left(10^{8} \mathrm{cfu} / \mathrm{mL} / \mathrm{B} 2\right)$. Therefore, the combination of the experimental treatment were as follows: A1B0, A1B1, A1B2, A2B0, A2B1, and $\mathrm{A} 2 \mathrm{~B} 2$. Parameters observed were antioxidant activity, and calcium and meat protein mass.

Antioxidant activity was analyzed according to procedure of Brand-Williams et al. (1995) using the 2.2-diphenyl-1-picrylhydrazyl (DPPH), and calculated with the formula as follow:

Table 1. Ingredients and Nutrient Compositions of the Experimental Basal Diet

\begin{tabular}{|c|c|c|}
\hline Ingredient & Starter & Finisher \\
\hline & \multicolumn{2}{|c|}{ 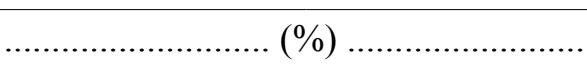 } \\
\hline Yellow corn & 53.30 & 54.50 \\
\hline Rice brand & 16.00 & 20.00 \\
\hline Soybean meal & 19.50 & 15.00 \\
\hline Fish meal & 10.00 & 9.30 \\
\hline $\mathrm{CaCO}_{3}$ & 0.70 & 0.70 \\
\hline Vitamin and mineral & 0.50 & 0.50 \\
\hline Total & 100.00 & 100.00 \\
\hline \multicolumn{3}{|l|}{ Nutrient Composition (\%) } \\
\hline Metabolizable energy $(\mathrm{kcal} / \mathrm{kg})^{*}$ & $2,879.55$ & $2,879.16$ \\
\hline Crude protein $* *$ & 19.67 & 17.73 \\
\hline Ether extract $* *$ & 6.42 & 6.35 \\
\hline Crude fiber** & 6.38 & 6.60 \\
\hline Methionine* & 0.42 & 0.40 \\
\hline Lysine* & 1.95 & 1.06 \\
\hline Calcium*** & 1.17 & 1.10 \\
\hline Phosporus $* * *$ & 0.68 & 0.68 \\
\hline
\end{tabular}

*Based on Table of Badan Standarisasi Nasional (2006) and National Research Council (1994).

**Result of chemical analysis at the Laboratory of Feed Science, Faculty of Animal Science, Hasanuddin University.

***Result of chemical analysis at the Laboratory of Nutrition and Feed Science, Faculty of Animal and Agricultural Sciences, Diponegoro University (2013). 
[(Absorbance of control - absorbance of the sample) / absorbance of control] x 100\%. Meat protein mass was measured starting with the determination of protein content using method of micro Kjeldahl Nitrogen (Apriyantono et al., 1989), and calculated with the formula of Suthama (2003) as follow: [mass of meat protein $=\%$ meat protein content $\mathrm{x}$ meat mass $(\mathrm{g})]$. Analogue to protein mass determination, calcium mass was initiated by measuring calcium content of meat using the method of atomic absorption spectrophotometer according to AOAC (1995) and continued to calculate calcium meat mass with the formula of Suthama (2003) as follow: [meat calcium mass $=\%$ meat calcium content $\mathrm{x}$ meat mass $(\mathrm{g})]$. Data were subjected to analysis of variance and followed by Duncan multiple range test at $5 \%$ probability when the treatment indicated significant effect.

\section{RESULTS AND DISCUSSION}

Feeding dahlia tuber powder as a source of inulin combined with Lactobacillus sp. showed significant effect $(\mathrm{P}<0.05)$ on antioxidant activity and meat protein mass, but not on meat calcium mass of crossbred kampong chicken. The highest value of antioxidant activity were achieved by the combination of dahlia tuber powder at $1.2 \%$ and Lactobacillus sp. At $2.4 \mathrm{~mL}\left(10^{8} \mathrm{cfu} / \mathrm{mL}\right)$ (A2B2) and significantly $(\mathrm{P}<0.05)$ different as compared to all other treatment combinations. On the contrary, the combination of $0.8 \%$ dahlia tuber powder with $2.4 \mathrm{~mL}$ Lactobacillus sp. (A1B2) resulted significantly $(\mathrm{P}<0.05)$ the lowest value of antioxidant activity same to the treatment without addition of Lactobacillus sp. (A1B0). However, the combination of dahlia tuber powder at the levels of $0.8 \%$ and $1.2 \%$ with $1.2 \mathrm{~mL}$ of Lactobacillus sp. (A1B1 and A2B1) were the same and indicated medium values (Table 2 ).

The present results suggested that additional Lactobacillus sp. can coorporate with endogenous lactic acid bacteria supported by the inclusion of inulin from dahlia tuber powder, and decreased pathogenic bacteria, such as $E$. coli. The decrease in pathogenic bacteria population was an indication of the improved health status of the gastrointestinal tract that bring about the increase in crossbred kampong chicken body resistance. This evidence supported by previous results (Krismiyanto et al., 2014) that E.coli count reduced with feeding inulin in starter period of crossbred native chicken. The improvement of health status of gastrointestinal tract implicated to the improved antioxidant activity in body tissue. The reduced pathogenic bacteria population can be assumed to have impact on the lightening body defence via phagocytocis load (Abbas and Litshman, 2009; Arief et al., 2010), and this mechanism in the present study was indicated by the higher value of antioxidant activity (Table 2). As it have been reported by Susanti et al. (2012) and Chen et al. (2013) that during the process of phagocytosis, phagocytic receptors that bind to bacterial pathogens sends a signal to activate the reactive oxygen species (ROS) such as superoxide anion-free radicals and $\mathrm{H}_{2} \mathrm{O}_{2}$ which can damage cells of pathogenic bacteria.

The mechanism of why antioxidant work causing the fluctuated value of activity can be explained by the existence of free radical superoxide anion neutralized by the endogenous antioxidant, such as superoxide dismutase (SOD). Sarker et al. (2010) described that the antioxidant activity was the ability to maintain the quality of the meat from the oxidation process. Based on the above mechanism, the increase in the number of lactic acid bacteria in the gut due to the feeding effect of inulin derived from dahlia tuber (Faradilla, 2015) was relevance with the increasing antioxidant activity as found in the present study. Therefore, the phenomenone of the increased antioxidant activity in the tissue can be associated with the decrease in gastrointestinal pathogenic bacteria number due to the supplementation of inulin from dahlia tuber powder in combination with Lactobacillus sp. Although the enzyme was not examined in the present study, it can be assumed that probiotic can release antioxidant, such as GSH-Px enzyme, that prevents oxidative damage by pathogenic bacteria in the gut. This enzymatic theory is consistent with Peran et al. (2006); Peran et al. (2007), and Rajput et al. (2013) that probiotic, by releasing GSH-Px enzyme as an antioxidant, can prevent oxidative damage due to irritation of the small intestine by pathogenic bacteria.

Naturally, the animal body produces GSH-Px enzyme that its formation was influenced by the intake level of methionine (Wang et al., 1997). The result of the present experiment, especially the treatments of $\mathrm{A} 2 \mathrm{~B} 1$ and $\mathrm{A} 2 \mathrm{~B} 2$, showed the increased meat antioxidant activity, so it can be assumed that methionine intake level was still at the normal range. The influence of methionine intake on the increase of antioxidant activity in this study (GSH-Px) was found in the treatment of 
Table 2. The Mean Value of Protein Massa, Massa Calcium and Antioxidant Activity

\begin{tabular}{lcccc}
\hline \multirow{2}{*}{ Level of Dahlia Tuber Powder } & \multicolumn{3}{c}{ Level of Lactobacillus sp. } & \multirow{2}{*}{ Mean } \\
\cline { 2 - 4 } & B0 & B1 & B2 & \\
\hline Antioxidant Activity (\%) & $5.612^{\mathrm{cd}}$ & $8.992^{\mathrm{b}}$ & $4.368^{\mathrm{d}}$ & $6.324^{\mathrm{b}}$ \\
$\quad$ A1 & $6.488^{\mathrm{c}}$ & $10.651^{\mathrm{b}}$ & $17.937^{\mathrm{a}}$ & $11.692^{\mathrm{a}}$ \\
A2 & $6.0498^{\mathrm{b}}$ & $9.8214^{\mathrm{a}}$ & $11.1526^{\mathrm{a}}$ & 9.008 \\
$\quad$ Mean & & & & \\
Calcium Mass (g/bird) & 7.687 & 7.388 & 9.863 & 8.313 \\
A1 & 9.587 & 9.551 & 9.116 & 9.418 \\
A2 & 8.637 & 8.470 & 9.489 & 8.865 \\
Mean & & & & \\
Protein Mass (g/bird) & $63.105^{\mathrm{b}}$ & $64.013^{\mathrm{b}}$ & $79.714^{\mathrm{a}}$ & 68.944 \\
A1 & $62.731^{\mathrm{b}}$ & $74.483^{\mathrm{ab}}$ & $65.134^{\mathrm{ab}}$ & 67.450 \\
A2 & 62.918 & 69.248 & 72.424 & 68.197 \\
$\quad$ Mean & & &
\end{tabular}

${ }^{a-b}$ Mean values within row with different superscript are significantly different $(\mathrm{P}<0.05)$.

${ }^{a-b}$ Mean values within column with different superscript are significantly different $(\mathrm{P}<0.05)$.

${ }^{\mathrm{a}-\mathrm{d}}$ Mean values among combinations within row and column with different superscript are significantly different $(\mathrm{P}<0.05)$.

A2B1 with the highest value of methionine intake $(0.104 \mathrm{~g} / \mathrm{bird} /$ day $)$, while that of A2B2 $(0.097$ $\mathrm{g} / \mathrm{bird} /$ day) was relatively same as those of A1B0 (0.099 g/bird/day) and A2B0 (0.100 g/bird/day). This result indicated that dietary inclusion of high levels of both dahlia tuber powder as a source of inulin and Lactobacillus sp. (A2B2) through their modifying effect on methionine utilization have a positive contribution to the increase of antioxidant activity in meat. However, the increase of meat antioxidant activity was not always followed by the improvement of meat mass protein because of methionine intake-dependent possibility, for this case, it can be compared between treatments A1B2 and A2B2. The difference biochemical phenomenone can be connected with the different level of methionine utilization for GSH-Px synthesis and protein synthesis. This finding is consistent with Wang et al. (1997), that there was a difference in the minimal level of methionine requirement for synthesis of GSH than that needed for protein synthesis.

Combination of $0.8 \%$ dahlia tuber powder without Lactobacillus sp. (A1B0) shows the lowest value of antioxidant activity and not significantly different with the combination of $0.8 \%$ dahlia tuber powder and $2.4 \mathrm{~mL}$ of Lactobacillus sp. $\left(10^{8} \mathrm{cfu} / \mathrm{mL}\right)$ (A1B2). This phenomenon showed that supplementation of low level of dahlia tuber powder combined with higher level of Lactobacillus sp. (A1B2) did not provide a good balance, so that the value of antioxidant activity is not higher than that of supplemental low level of dahlia tuber powder without addition of Lactobacillus sp. (A1B0). Combination of $0.8 \%$ dahlia tuber powder with $1.2 \mathrm{~mL}$ of Lactobacillus $\mathrm{sp} .\left(10^{8} \mathrm{cfu} / \mathrm{mL}\right)(\mathrm{A} 1 \mathrm{~B} 1)$ indicated higher antioxidant activity than combination of $0.8 \%$ dahlia tuber powder without Lactobacillus sp. (A1B0) because the treatment achieved the better balance state. Combination of $1.2 \%$ dahlia tuber powder with $1.2 \mathrm{~mL}$ and 2.4 $\mathrm{mL}$ of Lactobacillus sp. $\left(10^{8} \mathrm{cfu} / \mathrm{mL}\right)$, respectively (A2B1 and $\mathrm{A} 2 \mathrm{~B} 2$ ) proven that the combination was assumed to be optimal synbiotic because Lactobacillus sp. could evolved since it received the adequate supply of substrate ("food"). Therefore, high level of supplemental dahlia tuber powder combined with high level of Lactobacillus sp. (A2B2) was an efficient combination. Prebiotic compound when combined with probiotic (synbiotic) sustained the growth of the probiotic, and thus, increased stabilization and improvement of the probiotic effect (Awad et al., 2008; and Awad et al., 2009). The balance combination of dahlia tuber powder as a source of inulin and Lactobacillus sp. can be categorized to be the most positive effect as a synbiotic to 
increase antioxidant activity in meat as it has been discussed previously. On the other hand, the combination of high level of Lactobacillus sp. with low level of dahlia tuber powder did not show a positive effect as a synbiotic.

The decreasing intestinal $\mathrm{pH}$ due to the increasing number of beneficial bacteria as the part of this study results (Faradilla, 2015) may be associated with the higher absorption of calcium and protein which can contributes to the deposition into the meat. Lopez et al. (2000) and Scholz-Ahrens et al. (2007) reported that the substance of metabolite produced by nonpathogenic microbes in the gut can decreased the $\mathrm{pH}$ value so that causes the increased absorption of calcium. The lower intestinal $\mathrm{pH}$ has also an impact on the increase in protein absorption and further increasing protein metabolism for meat protein deposition (Saputri, 2012). However, feeding dahlia tuber powder as a source of inulin with additional Lactobacillus sp. did not affect meat calcium mass, because it can be assumed that the calcium absorption was mostly deposited into the bone since the birds were still at the growing period, thus, deposition in the meat did not show any differences. This result is consistent with the reports of Haryati and Supriyati (2010), and Chen and Chen (2004) that bone calcium content increased in connection with the decrease in the intestinal $\mathrm{pH}$ due to the fermentation of fructooligosaccharide which produced short chain fatty acids (butyrate, propionate and acetate) so that dissolved the insoluble calcium salts components.

Although the status of meat calcium did not specifically determined, calcium in the meat is assumed to be the form of salt and low calcium ion content. Calcium ion is known as an activator for muscle protease known as calcium-activated neutral protease (CANP), an enzyme is able to degrade muscle protein. When the level of calcium ion was low, it did not intentsely excert it activator function on CANP enzyme activity, and resulted the increase in meat protein mass (Table $2)$. This condition is in agreement with previous reports (Suthama, 2006; Jamilah et al., 2013) that protein mass of meat was influenced by meat calcium content in the free ion form as the activators of CANP enzyme. The present study showed the tendency that when the combination of inulin from dahlia tuber and Lactobacillus sp. was provided at whatever levels, most calcium was appeared to bound in salt form and the CANP activity was similarly low with the same consumption of calcium. Calcium in the form of ions can increased the degradative activity of CANP which brought about the decreased meat protein deposition (Suthama, 2006; Suthama et al., 2014), However, when the meat calcium mass in the form of calcium ions is low, although the total calcium is high, the mass of protein meat unchanged and still high. This phenomenon as described above is presumably occurred in the treatments of A1B2, A2B1, and A2B2. The capacity of protein deposited into the meat defined as meat protein mass as it has been descused previously depending on antioxidant activity and the condition of meat calcium mass based on the presence of calcium ion as an activator for muscle protease known as calciumactivated neutral protease (CANP). The highest meat protein mass was resulted by the combination of $0.8 \%$ dahlia tuber powder and 2.4 $\mathrm{mL}\left(10^{8} \mathrm{cfu} / \mathrm{mL}\right)$ Lactobacillus sp. (A1B2) but statistically similar to those of $1.2 \%$ dahlia tuber powder combined with $1.2 \mathrm{~mL}$ and $2.4 \mathrm{~mL}$ Lactobacillus sp., respectively (A2B1 and A2B2). When comparing among the three treatments of $\mathrm{A} 1 \mathrm{~B} 2, \mathrm{~A} 2 \mathrm{~B} 1$, and $\mathrm{A} 2 \mathrm{~B} 2$, the treatment of A2B1 can be considered as the approriate level of combination since it produced the high meat quality indicated by the high antioxidant activity and protein mass with slightly high calcium content.

\section{CONCLUSION}

Dietary inclusion of $1.2 \%$ dahlia tuber powder as a source of inulin and $1.2 \mathrm{~mL}$ Lactobacillus sp. $\left(10^{8} \mathrm{cfu} / \mathrm{mL}\right)$ can be an appropriate combination for the higher meat quality yield based on high antioxidant activity, meat calcium mass, and meat protein mass in crossbred kampong chicken.

\section{REFERENCES}

Abbas, A.K. and A.H. Lichtman. 2009. Basic Imunology: Function and Disorder of The Immune System. Saunder Elsevier, Philadelphia.

AOAC. 1995. Official Methode of Analytical of Assosiation Official Agriculture Chemistry. Washington DC.

Apriyantono, A., D. Fardiaz, N.L. Puspitasari, Y. Sedamawati and S. Budiyanto. 1989. Petunjuk Laboratorium Analisis Pangan. Institut Pertanian Bogor Press. Bogor. 
Arief, I.I., B.S.L. Jenie, M. Astawan, and A.B. Witarto. 2010. Efektivitas probiotik Lactobacillus plantarum 2C12 dan Lactobacillus acidophilus 2B4 sebagai pencegah diare pada tikus percobaan. Med. Pet. 33(3):137-143.

Awad, W., K. Ghareeb and J. Bohm. 2008. Intestinal structure and function of broiler chickens on diets supplemented with a synbiotic containing Enterococcus faecium and oligosaccharides. Int. J. Mol. Sci. 9(11):2205-2216.

Awad, W.A., K. Ghareeb, S. Abdel-Raheem and J. Bohm. 2009. Effects of dietary inclusion of probiotic and synbiotic on growth performance, organ weights, and intestinal histomorphology of broiler chickens. Poultry Sci. 88(1):49-56.

Badan Standarisasi Nasional (BSN). 2006. Pakan anak ayam ras pedaging (ayam broiler starter). Standar Nasional Indonesia (SNI) 01-3930-2006.

Brand-Williams, W., M.E. Cuvelier and C. Berset. 1995. Use of a free radical method to evaluate antioxidant activity. LWT-Food Sci. Technol. 28(1): 25-30.

Chen, Y.C. and T.C. Chen. 2004. Mineral utilization in layers as influenced by dietary oligofructose and inulin. Int. J. Poult. Sci. 3(7): 442-445.

Chen, W., X.Z. Zhu, J.P. Wang, Z.X. Wang and Y.Q. Huang. 2013. Effects of Bacillus subtilis var. natto and Saccharomyces cerevisiae fermented liquid feed on growth performance, relative organ weight, intestinal microflora, and organ antioxidant status in Landes geese. J. Anim. Sci. 91(2): 978-985.

Choudhari, A. S., Shinde and B. N. Ramteke. 2008. Prebiotics and probiotics as health promoter. Vet. World. 1: 59-6.

Faradilla, S. 2015. Pemberian Kombinasi Inulin Umbi Dahlia dan Lactobacillus sp. Terhadap Perkembangan Mikroba Usus dan Ketahanan Tubuh Ayam Kampung Persilangan. Master Thesis. Diponegoro University. Semarang.

Fuller, R. 1989. Probiotics in man and animal. J. Appl. Bacteriol. 66(1):365-378.

Haryani, Y., S. Muthmainah and S. Sikumbang. 2013. Uji parameter non spesifik dan aktivitas antibakteri ekstrak metanol dari umbi tanaman dahlia (Dahlia variabilis). J. Penel. Farmasi Indon. 1(2):43-46.
Haryati, T. and Supriyati. 2010. Pemanfaatan senyawa oligosakarida dari bungkil kedelai dan ubi jalar pada ransum ayam pedaging. J. Ilmu Ternak Vet. 15(4): 252-260.

Jamilah, N. Suthama and L.D. Mahfudz. 2013. Performa produksi dan ketahanan tubuh broiler yang diberi pakan step down dengan penambahan asam sitrat sebagai acidifier. J. Ilmu Ternak Vet. 18(4):251-257.

Kelly, G. 2008. Inulin-type prebiotics--a review: part 1. Altern. Med. Rev. 13: 315-329.

Krismiyanto, L., N. Suthama, and H.I. Wahyuni. 2014. Feeding effect of inulin derived from Dahlia variabilis tuber on intestinal microbes in starter period of crossbred native chickens. J. Indonesian Trop. Anim. Agric. 39(4): 217 - 223.

Lopez, H.W., C. Coudray, M.A. Levrat-Verny, C. Feillet-Coudray, C. Demigne and C. Remesy. 2000. Fructooligosaccharides enhance mineral apparent absorption and counteract the deleterious effects of phytic acid on mineral homeostasis in rats. J. Nutr. Biochem. 11(10):500-508.

National Research Council. 1994. Nutrient Requirements of Poultry. $9^{\text {th }}$ Revised Ed. National Academy Press. Washington DC.

Panda, A., S.R. Rao and M. Raju. 2009. Phytobiotics, a natural growth promoter. Poult. Int. Pp: 10-11.

Peran, L., D. Camuesco, M. Comalada, A. Nieto, A. Concha, J.L. Adrio, M. Olivares, J. Xaus, A. Zarzuelo, and J. Galvez. 2006. Lactobacillus fermentum, a probiotic capable to release glutathione, prevents colonic inflammation in the TNBS model of rat colitis. Int. J. Colorectal Dis. 21(8):737746.

Peran, L., S. Sierra, M. Comalada, F. LaraVilloslada, E. Bailon, A. Nieto, A. Concha, M. Olivares, A. Zarzuelo, J. Xaus and J. Galvez. 2007. A comparative study of the preventative effects exerted by two probiotics, Lactobacillus reuteri and Lactobacillus fermentum, in the trinitrobenzenesulfonic acid model of rat colitis. Br. J. Nutr. 97(1):96-103.

Pramono, D. 2006. Ayam hasil persilangan sebagai alternatif pengembangan usaha ternak unggas. Prosiding lokakarya nasional inovasi teknologi dalam mendukung usaha ternak unggas berdaya saing. Pusat Penelitian dan Pengembangan Peternakan. Bogor. 
Rahayu, B. W. I., A. E. P. Widodo and R. Sarunggalo. 2010. Penampilan pertumbuhan ayam persilangan kampung dan bangkok. J. Ilmu Pet. 5(2):77-81.

Roberfroid, M. B. 2007. Prebiotics : the concept revisited. J. Nutr. 137:830 - 837.

Rajput, I.R., Y.L. Li, X. Xu, Y. Huang, W.C. Zhi, D.Y. Yu, and W. Li. 2013. Supplementary effects of Saccharomyces boulardii and Bacillus subtilis B10 on digestive enzyme activities, antioxidation capacity and blood homeostasis in broiler. Int. J. Agric. Biol. 15(2):231-237.

Saputri, F. 2012. Pengaruh pemberian probiotik bakteri asam laktat (BAL) Pediococcus pentosaceus terhadap keseimbangan mikroflora usus dan trigliserida daging itik pitalah. Tesis. Universitas Andalas. Padang.

Sarker, S.K., S.R. Park, G.M. Kim and C.J. Yang. 2010. Hamcho (Salicornia herbacea) with probiotics as alternative to antibiotic for broiler production. J. Med. Plants Res. 4(5):415-420.

Scholz-Ahrens, K.E., P. Ade, B. Marten, P. Weber, W. Timm, Y. Acil, C.C. Gluer and J. Schrezenmeir. 2007. Prebiotics, probiotics, and synbiotics affect mineral absorption, bone mineral content, and bone structure. J. Nutr. 137(3):838-846.

Schrezenmeir, J. and M. de Vrese. 2001. Probiotics, prebiotics, and synbiotics approaching a definition. Am. J. Clin. Nutr. 73:361-364.

Shivayogeppa, J., A. Dinakara., G. Prabhuling., B.
S. Reddy, S. K Natraj and S. J. Prashanth. 2009. In vitro conservation studies in dahlia (Dahlia variabilis). Asian. J. Hort. 4:470472.

Susanti, R., A. Yuniastuti and R.S. Iswari. 2012. Aktivitas reactive oxygen species makrofag akibat stimulasi gel lidah buaya pada infeksi Salmonella typhimurium. J. MIPA 35(1):110.

Suthama, N. 2003. Metabolisme protein pada ayam kampung periode pertumbuhan yang diberi ransum memakai dedak padi fermentasi. J. Pengemb. Pet. Trop., Edisi Spesial, Oktober:44-48.

Suthama, N. 2006. Kajian aspek "protein turnover" tubuh pada ayam Kedu periode pertumbuhan. Med. Pet. 29 (2):47-53.

Suthama, N., H.I. Wahyuni and B. Sukamto. 2014. Protein Deposition and Protease Activity in Growing Kedu Chicken Fed Improved Diet. Proc. the 16th AAAP Animal Science Congress Vol. II, 10-14 November 2014, Yogyakarta.

Verdonk, J.M.A.J., S.B. Shim, P. van Leeuwen and M.W.A. Verstegen. 2005. Application of inulin-type fructans in animal feed and pet food. Br. J. Nutr. 93: 125-138.

Wang, S.T., H.W. Chen, L.Y. Sheen and C.K. Lii. 1997. Methionine and cysteine affect glutathione level, glutathione-related enzyme activities and the expression of glutathione s-transferase isozymes in rat hepatocytes. J. Nutr. 127(11):2135-2141. 